\title{
Research-based evaluation of customer project courses in agricultural sciences
}

\section{Kymäläinen, Hanna-Riitta}

IATED Academy

2018-07

Kymäläinen , H-R , Kokkonen , T , Muukkonen , H, Mäkelä , P , Seppänen , M \& Lakkala , M 2018 , Research-based evaluation of customer project courses in agricultural sciences . in L Gómez Chova , A López Martínez \& I Candel Torres (eds), EDULEARN18 Proceedings : 10th International Conference on Education and New Learning Technologies July 2nd-4th, pÿ2018 Palma, Spain. EDULEARN Proceedings, no. 18, IATED Academy, Spain , pp. 1505-1514 , 10th International Conference on Education and New Learning Technologies , Palma de Mallorca , Spain , 02/07/2018 . https://doi.org/10.21125/edulearn.2018.0466

http://hdl.handle.net/10138/244935

https://doi.org/10.21125/edulearn.2018.0466

unspecified

publishedVersion

Downloaded from Helda, University of Helsinki institutional repository.

This is an electronic reprint of the original article.

This reprint may differ from the original in pagination and typographic detail.

Please cite the original version. 


\title{
RESEARCH-BASED EVALUATION OF CUSTOMER PROJECT COURSES IN AGRICULTURAL SCIENCES
}

\author{
Hanna-Riitta Kymäläinen ${ }^{1}$, Tuomo Kokkonen ${ }^{1}$, Hanni Muukkonen², \\ Pirjo Mäkelä ${ }^{1}$, Mervi Seppänen ${ }^{1}$, Minna Lakkala ${ }^{3}$ \\ ${ }^{1}$ University of Helsinki, Department of Agricultural Sciences (FINLAND) \\ ${ }^{2}$ University of Oulu, Faculty of Education (FINLAND) \\ ${ }^{3}$ University of Helsinki, Faculty of Educational Sciences (FINLAND)
}

\begin{abstract}
Work life relevance is emphasized these days in higher education. In addition to domain-specific knowledge and skills, students should learn general work life competencies, such as team work, networking, project work and digital skills. At the University of Helsinki, agricultural science students' work life skills are promoted in a project course. The 5 ETCS course has been held for B.Sc. and M.Sc. students in 2016 and 2017. The course in 2016 had eight students and three supervisors in two project teams; the course in 2017 had 15 students in four teams, and six supervisors (university teachers). Each team had its own external client from businesses and national government departments.
\end{abstract}

The course implementation was examined from a design-based research approach. The aim of the study was to evaluate the summative evaluations made by all groups participating in the course, receive research-based knowledge about improving the course design further, and to try out instruments and methods that can be used in educational practice to assess participant satisfaction and competence development during courses about work life. An online questionnaire was used to examine the evaluations of the supervisors and students about the success of the course and the competencies gained by the students (Collaborative Knowledge Practices Questionnaire, CKP). Interviews were used to examine the views of the clients concerning the realization and development of the course. The data were analysed using quantitative and qualitative methods.

The project process was mostly graded the same by the evaluators (students, supervisors and clients), but most student groups gave the report a higher grade than the other evaluators did.

Students' evaluations were that they had acquired knowledge work competencies well, particularly the development of shared objects, the integration of individual and collaborative working and persistent development of knowledge objects. The students particularly appreciated team work for achieving common goals, development of project work and work life skills, interesting project topics and interaction with the customers. Challenges were the open assignments and related uncertainty of working methods, coordination of group work and students' inadequate skills in relation to project work requirements. The tight schedule of 11 weeks in 2016 led to the course being extended to 16 weeks in 2017.

All clients evaluated their participation in the course as being positive. They appreciated being able to help students to practice work life skills and the university to develop teaching. Collaboration was seen as a good way to create contacts with students from the viewpoint of future workplaces. Project work outcomes provided new information for the development of the client organizations or supplemented and strengthened earlier views. As targets for improvement, the clients mentioned better definition of appropriate assignments for student teams and the development of interaction practices, e.g. by organizing virtual meetings.

For the supervisors, the motivated working of the students and finishing of the projects in time were positive aspects. It was challenging to define appropriate topics for the client assignments, requirements of the course in relation to the skills of the students and timing of the course as well as their own time management.

All parties experienced work life-oriented project courses as necessary and rewarding for all parties. Research-based evaluation provided useful information for developing the course design further.

Keywords: Project course, development, research. 


\section{INTRODUCTION}

Work life relevance is emphasized these days in higher education along with domain-specific studies. For example, the University of Helsinki, Finland, has stressed that work life orientation should be included in both BSc and MSc degrees [1]. General work life competencies are connected with team work, networking, project work and digital skills.

Project courses [2] offer the students an opportunity to learn work life skills and to increase work life connections. The aim of project work is to develop analytical thinking and problem-solving skills as well as to apply the knowledge and skills acquired to solving problems in one's subject field [3], [4]. The learning outcomes of the agricultural sciences project course have been stated as follows: after passing the course the student will be able to a) apply the knowledge of agricultural science in practice, b) act in a project group in various roles, c) prepare a project plan, d) carry out projects according to the plan and e) produce a project report with the group that matches the project assignment [5]. The work life partners act as the clients of the student teams, and the project themes and assignments arise straight from the needs of employers. In the projects, the students solve practical problems systematically and by accepting responsibility for their own working and learning [6], [7]. The authenticity of the task engages the student in the realization of the project and in learning [7].

In the projects, the students utilize and combine both generic skills and domain-specific substance knowledge [3]. Projects are realized in groups; project learning is a form of collaborative learning [8], [9]. According to present understanding, expertise is based on individual thinking and cognitive knowhow, and it is collective by nature [10]. The development of expertise requires participation in collaboration with professionals of the field and interaction with other experts [11], [12]. Particularly in modern knowledge work that the academically educated persons mostly do, the work of experts is directed to improving the predominant practices, looking for new solutions and collaborative development of shared objectives [13]. Study methods that simulate the practices of knowledge creation in real work life help the students to develop the skills of knowledge work needed in such tasks. Project-based learning is a good example of that: it engages the students to produce significant and tangible results in cooperation with the stakeholders [14].

Research data were collected from people involved in the newly developed 2016 and 2017 project courses in agricultural sciences for evaluating the course implementation and for research-based developing of the course. The research questions were the following:

- Were there differences in the summative evaluations based on the evaluation matrix between student teams, supervisors, and clients?

- How did the students and supervisors evaluate the acquiring of knowledge work competencies by the students in the course?

- How did the students, clients and supervisors evaluate their experiences of participating, and the outcomes of the course?

\section{METHODOLOGY}

\subsection{Course design}

The context of the study was two project courses in agricultural science at the University of Helsinki, Finland. Students as teams prepared a project for an external client from businesses and national government departments. The client organization of each team was represented by one or several persons. The potential clients offered the project themes in advance, which were specified by the coordinators of the course (teachers at the university) and representatives of the client organizations, if needed. The students applied for entry to the course using a letter in which they also announced the project topics of their interest. The coordinator teachers formed the final teams on the basis of those wishes. The responsibility of a supervisor (a university teacher) was to supervise the project work of a team, participate in meetings, give comments on the reports of his/her group and participate in the final grading. Three coordinator teachers, some of whom also acted as supervisors of teams, were responsible for the course as a whole. The courses consisted of three meetings for all groups and supervisors (two of them also including the clients), some supervision and client meetings (see the timetable of the course in Fig. 1) as well as independent working by the teams. 


\begin{tabular}{|c|c|c|c|c|c|}
\hline Wh & Mon & Tue & Wed & Thu & Fri \\
\hline \multirow[t]{2}{*}{3} & $\begin{array}{l}2.5 \text { h Classroom, } \\
\text { beginning (students, } \\
\text { supervisors) }\end{array}$ & \multirow{2}{*}{\multicolumn{3}{|c|}{ 1. Supervision meeting (time window): promoting the project plan }} & \\
\hline & $\begin{array}{l}1.5 \mathrm{~h} \text { Client meeting in } \\
\text { groups: clarifying the } \\
\text { project topic, allocating } \\
\text { the project meetings }\end{array}$ & & & & \\
\hline 4 & & & & $\begin{array}{l}\text { Return to Moodle (project } \\
\text { plan) }\end{array}$ & \\
\hline 5 & \multicolumn{5}{|c|}{ 2. Supervision meeting (time window): preparing of the client meeting; invitation and agenda for the client meeting a week before the meeting } \\
\hline 6 & \multicolumn{5}{|c|}{ The realization of the project starts at the latest now. 2. project meeting (client meeting, time window): discussion about the project plan } \\
\hline 7 & \multicolumn{3}{|c|}{ Discussion with the supervisor if needed. Realization of the project going on. } & $\begin{array}{l}\text { Return of the elaborated } \\
\text { project plan to Moodle. }\end{array}$ & \\
\hline 8 & \multicolumn{5}{|c|}{ Realization of the project going on. Discussion with the supervisor/client if needed, supervision meeting when needed. } \\
\hline 9 & \multicolumn{5}{|c|}{$\begin{array}{l}\text { 3. Supervision meeting (time window): situation of the temporary report, advices for the report and project, evaluation of working of the group. } \\
\text { Connection to the client if needed. }\end{array}$} \\
\hline 10 & \multicolumn{5}{|c|}{ Realization of the project } \\
\hline 11 & & & & & $\begin{array}{l}\text { Return to Moodle } \\
\text { (temporary report) }\end{array}$ \\
\hline 12 & & & $\begin{array}{c}4 \mathrm{~h} \text { Classroom (students \& } \\
\text { supervisors): evaluation of } \\
\text { temporary reports }\end{array}$ & \multicolumn{2}{|c|}{$\begin{array}{l}\text { 3. Project meeting (time window): analyzing the } \\
\text { temporary report, planning further improvements }\end{array}$} \\
\hline 13 & \multicolumn{5}{|c|}{ (time window continues if needed) Realization of the project, working with the final report } \\
\hline 14 & \multicolumn{5}{|c|}{ Realization of the project, working with the final report } \\
\hline 15 & & $\begin{array}{l}\text { Return to Moodle: draft of } \\
\text { the final report }\end{array}$ & & & \\
\hline
\end{tabular}

Figure 1. The schematic course timetable, year 2017.

For the course degree, student groups, supervisors and clients each made a summative evaluation at the end of the course using the relevant parts of a common matrix (Table 1). The final grade of each team was a conclusion of all summative evaluations; this decision was made by the supervisors.

Table 1. Evaluation matrix of the course, year 2017.

\begin{tabular}{|c|c|c|c|c|c|}
\hline $\begin{array}{c}\text { Learning } \\
\text { objective and } \\
\text { evaluation } \\
\text { criteria }\end{array}$ & 5 excellent & $4^{*}$ & $3 \mathrm{good}$ & $2^{*}$ & 1 passable \\
\hline $\begin{array}{l}\text { Project report: } \\
\text { realization of } \\
\text { the } \\
\text { assignment } \\
\text { and quality of } \\
\text { product }\end{array}$ & $\begin{array}{l}\text { The assignment was realized } \\
\text { excellently. All aims were } \\
\text { answered, the report is versatile } \\
\text { and profound, existing knowledge } \\
\text { is utilized, and creative solutions } \\
\text { are produced. The report is } \\
\text { technically of high quality and } \\
\text { meets the reporting requirements } \\
\text { of the Department. }\end{array}$ & & $\begin{array}{l}\text { The assignment was realized. } \\
\text { Most aims were answered, } \\
\text { the report is a wholeness, } \\
\text { existing knowledge is utilized. } \\
\text { Solutions are not very } \\
\text { innovative. The report is } \\
\text { technically clear. }\end{array}$ & & $\begin{array}{l}\text { The assignment was partly } \\
\text { realized, but there was a lack } \\
\text { in some sub aims. The report } \\
\text { is diffuse, little existing } \\
\text { knowledge is utilized, the } \\
\text { solutions are foreseeable. The } \\
\text { report contains all required } \\
\text { parts, but the technical quality } \\
\text { is poor. }\end{array}$ \\
\hline $\begin{array}{l}\text { Project } \\
\text { process }\end{array}$ & $\begin{array}{l}\text { All group members participated } \\
\text { actively. The rules created were } \\
\text { obeyed. Time management was } \\
\text { good. Meetings and products } \\
\text { were documented } \\
\text { comprehensively and carefully. } \\
\text { Files are named clearly. } \\
\text { Communication with client and } \\
\text { supervisor was fluent. Possible } \\
\text { problems were solved together. }\end{array}$ & & $\begin{array}{l}\text { All group members } \\
\text { participated in working. The } \\
\text { rules created were mainly } \\
\text { obeyed. Time management } \\
\text { was fair. Meetings and } \\
\text { products were documented. } \\
\text { There is confusion in naming } \\
\text { of the files. Communication } \\
\text { with client and supervisor was } \\
\text { fairly fluent. Problematic } \\
\text { situations hindered working. }\end{array}$ & & $\begin{array}{l}\text { Work division between group } \\
\text { members was uneven. The } \\
\text { rules created were poorly } \\
\text { obeyed. There were clear lack } \\
\text { in time management, } \\
\text { documentation of meetings, } \\
\text { naming of files and } \\
\text { communication with client and } \\
\text { supervisor. Problematic } \\
\text { situations significantly } \\
\text { hindered working. }\end{array}$ \\
\hline
\end{tabular}

\footnotetext{
* Does not meet all requirements of the next higher grade but exceeds the next lower level
} 


\subsection{Participants}

Students $(N=23)$ participating in the courses were from B.Sc. and M.Sc. degree programs in agricultural sciences. All eight students from the first course and 12 students $(80 \%)$ from the second course answered the student questionnaire. The average age of the respondents was 27.8 years and 18 of them $(90 \%)$ were female. Supervisors of student teams were university lecturers and professors of the Department. The clients were public organizations or companies working in the field of agriculture. Numeric features of the two courses are presented in Table 2.

Table 2. Participants and duration of the two project courses.

\begin{tabular}{c|c|c|c|c|c}
\hline Year & $\begin{array}{c}\text { Students } \\
(\mathrm{n})\end{array}$ & $\begin{array}{c}\text { Teams } \\
\text { and }(\mathrm{n})\end{array}$ & $\begin{array}{c}\text { Client } \\
\text { organizations }(\mathrm{n})\end{array}$ & $\begin{array}{c}\text { Supervisors } \\
(\mathrm{n})\end{array}$ & $\begin{array}{c}\text { Duration of the } \\
\text { course (weeks) }\end{array}$ \\
\hline 2016 & 8 & 2 & 2 & 3 & 11 \\
\hline 2017 & 15 & 4 & 3 & 6 & 16 \\
\hline \hline
\end{tabular}

\subsection{Data collection and analysis}

The summative evaluations given by the supervisors, clients and students themselves for the process and outcomes using the evaluation matrix were examined through descriptive analysis.

For the present study, an online questionnaire was used to examine the students' and supervisors' assessments about the competencies learned by the students during the course (Collaborative Knowledge Practices Questionnaire, CKP [15]). The questionnaire is based on pedagogical design principles of collaborative knowledge creation [16]. In the students' questionnaire, there were two open-ended questions for evaluating course experiences: (What was positive or effective? What was challenging or disturbing?) and 27 statements for evaluating competencies in knowledge work (e.g. "During the course, I learned to take responsibility for common group work" or "...to collaborate with representatives from different domains"). The statements were rated on a five-point Likert scale ranging from 1 (not at all) to 5 (very much). The scales of the questionnaire were 1 . Learning to collaborate on shared objects, 2. Integrating individual and collaborative efforts, 3. Development through feedback, 4. Persistent development of knowledge objects, 5. Understanding various disciplines and practices, 6. Interdisciplinary collaboration and communication, and 7. Learning to exploit technology. The supervisors' questionnaire included open-ended questions about pedagogical practices and outcomes of the course (What succeeded? What failed?); in addition, using the same statements as the students, the supervisors evaluated how well the students, in the supervisor's opinion, acquired knowledge work competencies during the course. The representatives of the client organizations were interviewed with a semi-structured interview as individuals or groups (if several persons represented the same organization). The interviews focused on the experiences of participants and outcomes of the course from the viewpoint of the client.

The data were analysed with quantitative and qualitative methods. The statistical analysis of the questionnaire scales showed that the scale reliabilities were good: they ranged from 0.69 to 0.88 (Cronbach's Alpha), similarly as reported in [15]. A comparison of means with a t-test was carried out to study the differences between scale means in the two courses and then the difference of scale means between students and supervisors. The open answers of the students and client interviews were analysed using a thematic content analysis [17]. First, text pieces containing single mentions related to the realization or participation experiences by the respondents or interviewees were selected for coding. Of these mentions, things that were experienced as positive/impressive or challenging/disruptive were analysed separately. In a more detailed analysis, codes developed in an earlier study [14] were applied: general issues (general evaluation of the course, timetable etc.), tasks (features and experiences of tasks), guidance (quality and sufficiency of instructions and guidance), collaboration (group work, interaction among the participants) and outcomes (learning, benefits and products). A descriptive summary was written from the suggestions for improving the course implementation of the supervisors in the questionnaire answers, and the clients in the interviews. 


\section{RESULTS}

\subsection{Summative evaluations for the course degrees}

In most cases, the project process was evaluated as having a higher grade than the report (Table 3 ). The students' self-evaluations were made as teams, according to the instructions given; however, in one team (2017b) students reported on the evaluation individually. Most team processes (exceptions: one student in team 2016b and one team 2017d) were graded as 5 . The project process was mostly graded the same by all evaluators (exception 2017d, which was graded lower by the supervisors). In most cases (exception: team 2016b) students gave the report a higher grade than the clients and/or supervisors. Following the evaluation matrix (Table 1), shortcomings in the reports were included that the solutions were not very creative, and in processes with weaknesses, documentation or communication with the client was partly not fluent.

Table 3. Summative evaluations for the course degree. Scale 1-5; $5=$ excellent, $1=$ passable.

\begin{tabular}{|c|c|c|c|c|c|c|c|c|}
\hline \multirow[t]{2}{*}{ Year } & \multirow[t]{2}{*}{ Team } & \multicolumn{2}{|c|}{ Student teams } & \multicolumn{2}{|c|}{ Clients } & \multicolumn{2}{|c|}{ Supervisors } & \multirow[t]{2}{*}{ Final grade } \\
\hline & & $P$ & $\mathrm{R}$ & $P$ & $\mathrm{R}$ & $\mathrm{P}$ & $\mathrm{R}$ & \\
\hline \multirow[t]{2}{*}{2016} & a & 5 & 4 & 5 & 4 & 5 & 4 & 5 \\
\hline & $b$ & $5\left(3^{*}\right)$ & 5 & $5\left(3^{*}\right)$ & 4 & $5\left(3^{*}\right)$ & 4 & $5\left(3^{*}\right)$ \\
\hline \multirow[t]{4}{*}{2017} & a & 5 & 4 & 5 & 3 & 5 & 3 & 4 \\
\hline & $b$ & 5 & 4 & 5 & 4 & 5 & 3 & 4 \\
\hline & c & 5 & 5 & 5 & 4 & 5 & 5 & 5 \\
\hline & $d$ & 4 & $3.3^{* *}$ & 4 & 3 & 3 & 3 & 3 \\
\hline
\end{tabular}

*For one student in a team due to not working till the end of the project.

${ }^{* *}$ Calculated as a mean from individual evaluations

\subsection{Students' acquisition of knowledge work competencies according to the questionnaire statements}

According to the questionnaire responses, the students reported that they had acquired various knowledge work competencies in both years (Fig. 2). Higher scores were given particularly to the development of a shared object, combining individual and collaborative work, and persistent development of objects. In the first year, when a new learning environment (OneDrive in addition to Moodle) was taken into use, learning to exploit technology in collaboration was evaluated higher ( $\mathrm{M}=$ $3.89, \mathrm{SD}=0.52)(\mathrm{t}(27)=2.34, \mathrm{p}<0.05, \mathrm{~d}=0.95)$ compared to the 2017 course $(\mathrm{M}=3.24, \mathrm{SD}=$ 0.82 ). The lowest means were in the measures of learning interdisciplinary collaboration, which was expected since the students' background was in the same discipline. No other statistical differences were found.

In both years, although the same competencies were assessed, the supervisors evaluated the development of the competencies of the students higher than the students did. This observation is in accordance with an earlier study [15]. However, a statistically significant difference was found only for Learning to exploit technology, as students' responses were lower $(M=3.29, S D=0.77)(t(27)=$ $-2.13, p<0.05, d=0.88$ compared to supervisors' responses $(M=3.92, S D=0.66)$. Some of the supervisors reported the same in 2016 and 2017. The evaluations of the supervisors as a whole were lower in 2017 than in 2016, which was at least partly because the respondents "learnt" from the results of the previous year and adjusted the 2017 answers to be closer to the students' answers from the earlier year. 


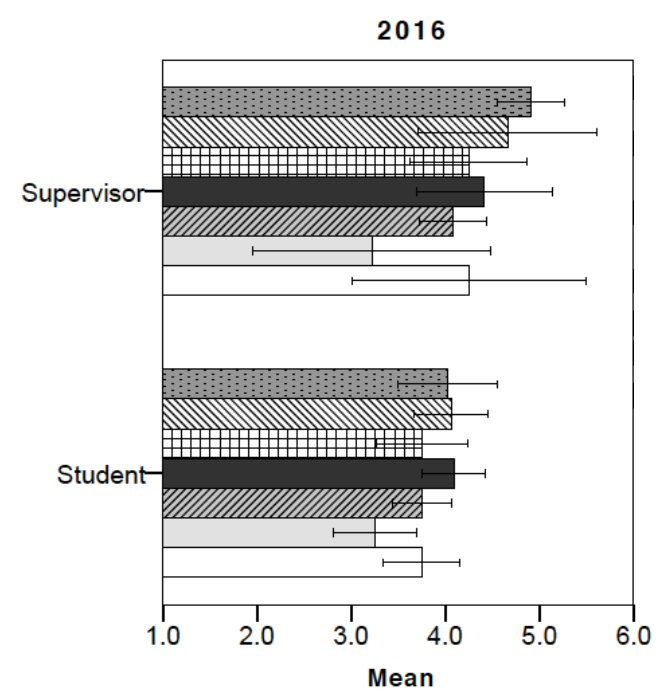

Error Bars: $95 \% \mathrm{Cl}$

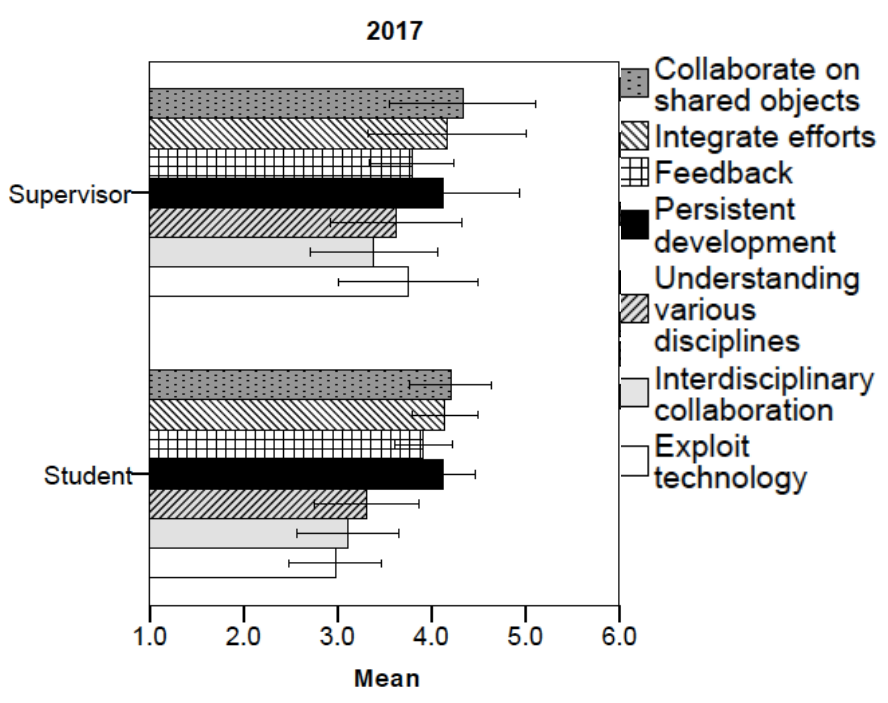

Error Bars: $95 \% \mathrm{Cl}$

Figure 2. Students' and supervisors' assessments of students' acquisition of knowledge work competencies in 2016 (left) and 2017 (right). Bar = mean, line = 95\% confidence interval.

\subsection{Course experiences according to the qualitative data}

\subsubsection{Course experiences by the students}

From the open answers of students in the two years, there were 54 positive and 28 critical mentions (Fig. 3).

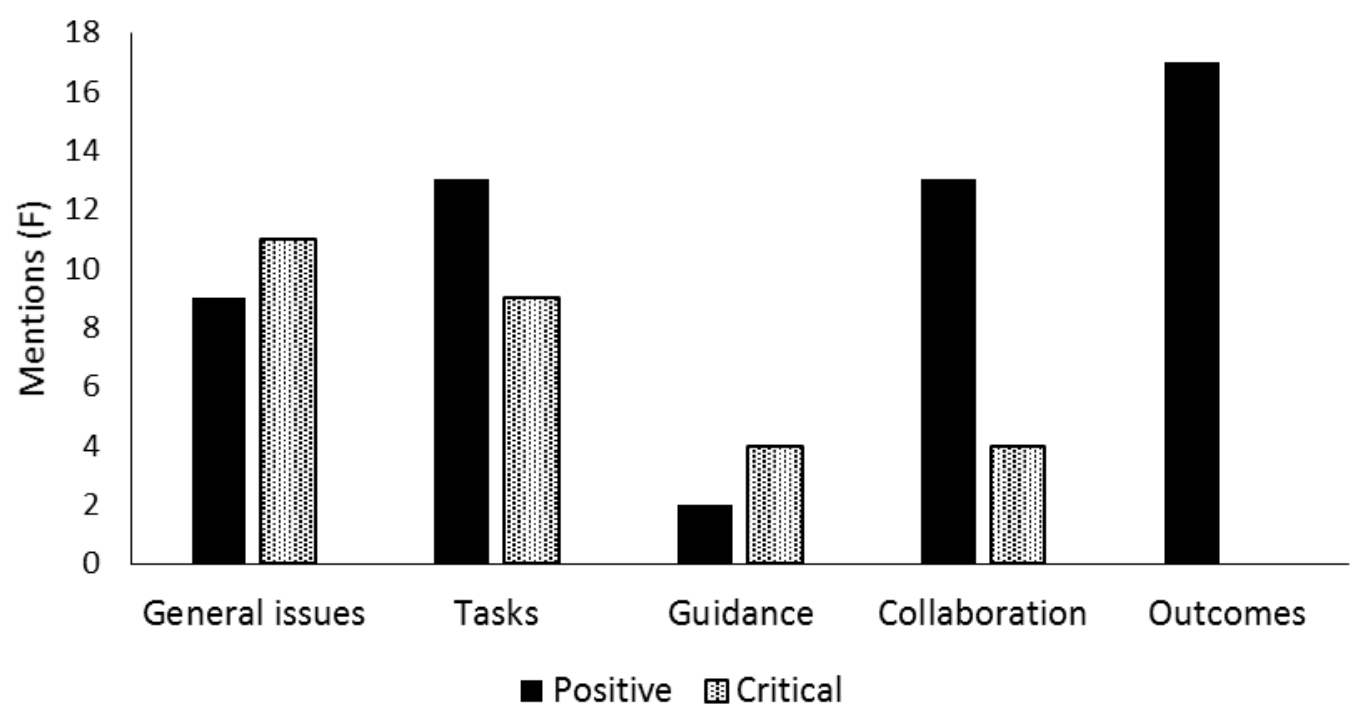

Figure 3. Evaluations of the students of the course experiences as frequencies of answers classified in each coding category.

The outcomes of the course were clearly the most positively experienced thing in the answers of the students; in particular, mentions concerned learning project working skills, networking and learning new things in general. Concerning the tasks, positively mentioned aspects included carrying out the project work, interesting project topic and responsibility given to the students (e.g., the opportunity to practice project working for the future ("I would like to have more courses like this as obligatory at university because the working life project is an important part of work"). Critical mentions of the tasks were connected to challenges related to carrying out project work: e.g. starting the work, changing plans and handling of results. Collaboration both in a student team as with the client were also experienced mainly as positive. Critical issues for the students concerning collaboration related to uneven division of labour in the team, consolidation/coordination of timetables and shortcomings in 
communication, but there were only four mentions of these. On one hand, a few comments related to guidance were about good and relevant feedback from the supervisors, but on the other hand, experiences about supervision were scarce. The course as a whole gained more negative than positive mentions by the students, but almost all the negative mentions were related to the timetable of the course in the first year (2016) (e.g., "Time resources and extent of the work related to each other $>$ too hurried").

\subsubsection{Clients' experiences of participation and outcomes of the courses}

From the client interviews, 92 mentions including evaluation of and participation in the course were selected for the analysis. Of these, 66 included positive and 26 critical opinions (Fig. 4).

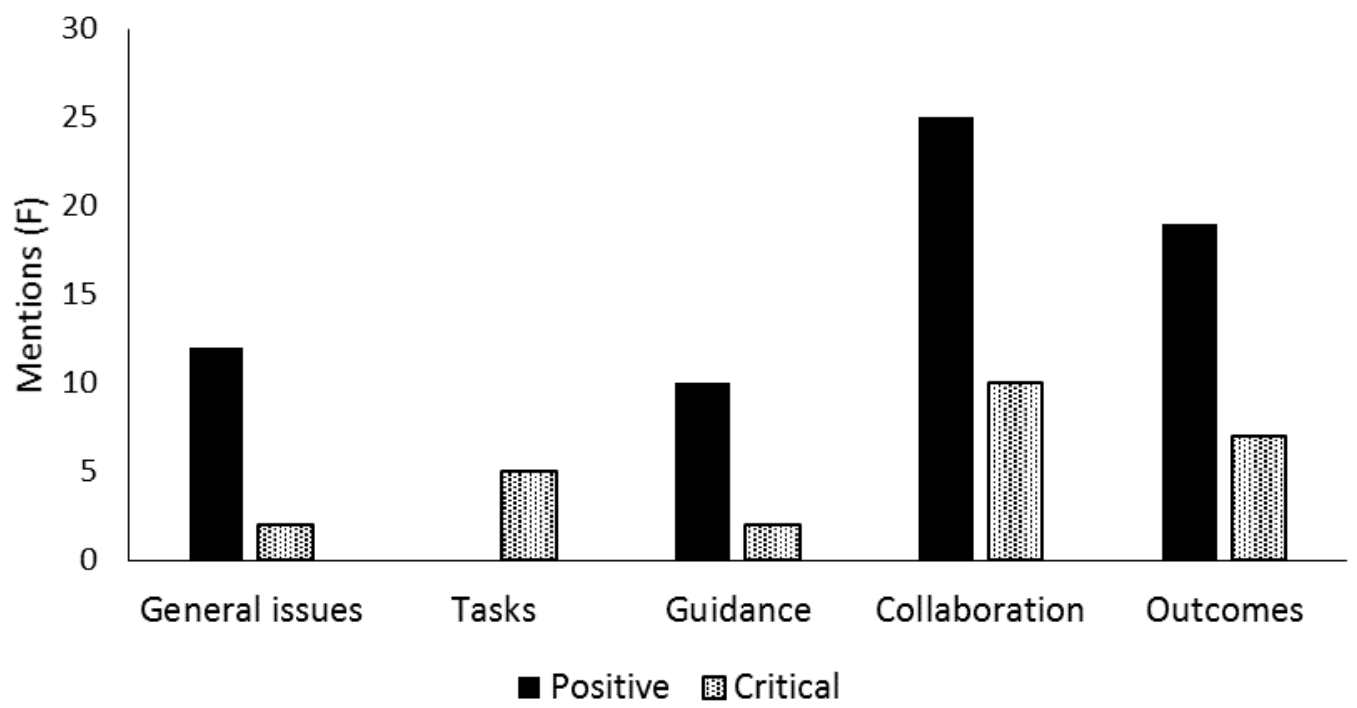

Figure 4. Evaluations of the clients of experiences of the courses as frequencies of answers classified in each coding category.

The clients often mentioned cooperation with the students and its fluency (communication, discussions, division of labour in the teams, obeying the timetable and rules) from a positive point of view; e.g., "The dialogue in both the meetings and between meetings by e-mail, or otherwise the dialogue through which both know what the other is waiting for, I think that it worked well here." Critical mentions about collaboration focused on the need to clarify their own role as a client and some minor shortcomings in communication in their own project team. Concerning the outcomes of the course, the positive mentions by the clients were connected to three points: successful completion of the project assignment in general; the project report and its results as a product of the project work; and the new insights and ideas obtained from the students. Critical comments about outcomes related to problems in the data collection methods (questionnaires, interviews) in the three projects, and report content that was more modest than what had been expected in two projects. Concerning student guidance, the clients were mainly satisfied with their own input; a couple of critical mentions were connected to the resources available in their own organization of the project work. The clients were not fully aware of the supervisors' guidance practices. Critical comments about the course tasks were all about the difficulty of defining and outlining the project assignment for this type of course. As in the student opinions, critical comments about the course in general were connected to the tight timetable of the first course, otherwise the implementation of the course and participation as a client received very positive comments (e.g. "In my opinion it was very nice, somehow very nice and somehow refreshing experience in this spring.")

In the interviews, the clients presented few suggestions for development of the course. Representatives of three client organizations suggested that modern digital technology could be utilized more in the communication between the student and clients, for example by organizing video meetings. Similarly, three clients suggested that there could be more interaction between the students and the clients, particularly at the beginning of the course. Three clients also reported that a more multidisciplinary and heterogeneous assembly of course participants would be interesting and beneficial to them. One client wished for more meetings with the project team and one suggested deeper evaluation of the project topics with the supervisors before the course. 


\subsubsection{Supervisors' participation experiences and outcomes from the courses}

Supervisors of the teams reported the following issues as positive regarding the project course: motivated work by the students; successful collaboration with the clients; finalization of the projects in time; and the satisfaction of the clients. In addition, in the comments by the supervisors, collaboration and division of responsibilities between the supervisors were emphasized as being important issues for successful management of the course. The supervisors mentioned appropriate definition of the project assignments by the clients and the requirements of the course in relation to students' real abilities and the timing of the course as challenges. In addition, the supervisors commented that their role as a supervisor and division of labour between the supervisors was not always clear. Suggestions for improvement included adjusting the learning objectives of the course, better definition of the client assignments, better support for idea generation and the planning phase of the project work, developing the contents and working methods for common course meetings, strengthening students' knowledge and skills in research methodology, and clarifying the division of responsibilities between the supervisors. In addition, for the first course (in 2016), prolonging the course duration was suggested, and this was implemented the next year. The need to find the means to persuade more students to undertake the project courses was also mentioned.

\subsection{Discussion}

The evaluation matrix worked well, and no complaints were received by the supervisors from the students or clients. The matrix covered the stated targets of learning. However, the learning objectives had been formulated in a tangible manner ("the student can apply the knowledge of agricultural science in practice, act in a project group and its various roles, prepare a project plan, carry out the project according to the plan and produce a project report with the group that matches the project assignment given"). Later, also referring to the feedback from the supervisors, we need to consider whether the learning targets should be more detailed, e.g. "is able to act in an expert manner in processing, evaluating and producing of knowledge", "is able to act in collaboration with clients", "is able to work as part of a team", "is able to plan and lead a project" or "is able to evaluate and give feedback on the functioning of a team". This would probably ease the burden of evaluation and provide guidance to the students about the targets and evaluation.

Although it was clearly stated in the instructions that the student self-evaluation had to be made as a team, in the present courses the individual evaluations of one group did not cause practical harm to the evaluation. The project process was mostly graded the same by all evaluators which supports the use of the current type of evaluation matrix. However, since most student groups gave the report a higher grade than the other evaluators, the background of the evaluator and/or role related to the report to be evaluated seem to have some connection in the way the evaluation matrix is interpreted. The multi-evaluator system also makes visible the different opinions given by the evaluator groups.

According to the responses to the CKP questionnaire, the students' evaluation was that they had acquired knowledge work competencies well during the project course, particularly the development of shared objects, the integration of individual and collaborative work and persistent development of knowledge objects. These quantitative results are in line with the qualitative analysis results about what the students mentioned as positive in the course experience and outcomes (collaboration, succeeding in the project work, having responsibility). The results also indicate that the learning experienced is related to the overall context and course practices; in the second course year, the digital tools used were no longer new to the students of the university, which might be a reason for lower evaluation of the learning of digital practices. In the first course year, supervisors were more optimistic than students about increasing their competence level but they learned to consider the development more realistically based on the feedback from the first year.

According to the open answers by the students, the experiences observed were similar to those of an earlier study [14]. In that study, the evaluated outcomes of a course based on similar client project work (learning new skills, output of the project) received many positive mentions, while the timetable was mentioned as a challenge. In both studies, students ranked the project task itself as very rewarding and challenging. In 2016, the 11-week timetable was seen as being too tight, so the length of the course was increased to 16 weeks the following year. The confusion at the beginning of the course, mentioned by the clients, was also observed in the opinions of the students participating in the course in 2016 [18], and meetings with clients were thus experienced as being essential for successful progress of the project. 
Although the project work appeared to be challenging for the students, participation in the project course turned out to be mainly a good learning experience. A prerequisite, however, is putting a lot of effort into organizing the course and into supervising the students. These issues were taken into account in the investigated course implementation, but the courses will be further developed according to the feedback. In an earlier study [19] it was found that students particularly found the beginning phase of the course to be challenging, when it was changed from teacher lecturing to team work. The experience of challenge in the present study might also be connected to a novel course type for the participating students. Meeting with the client helped the student teams to progress in their project work. According to [18], the experience of the students participating in a project course was that their earlier studies in agricultural sciences gave them the basic capabilities for carrying out surveys in their projects and courage for presenting their opinions, when the basic concepts of the discipline were already familiar.

In addition to the development of pedagogical practices by the supervisors and teachers, a prerequisite for project courses is also creating new ways for work life collaboration and co-teaching these practices do not develop at one time but need interested teachers, several trials and common reflection on experiences. This had already been realized in the two courses examined. A lot of time had been used for planning and preparation of the courses, and the latter course was developed according to the experiences and research results from the first course. The project courses in agricultural sciences are a continuum for another work life skills course [20], for which another study book was prepared [21]. The courses have been developed through interactions with other stakeholders of the University of Helsinki [2]. Committed supervisors were obtained for all the team projects for the present courses, which was significant for the success of the projects and the courses. Acquisition of a range of project topics and supervisors requires openness to new practices by the teachers, willingness to collaborate with stakeholders, and agile actions.

\section{CONCLUSIONS}

The students reported that they had acquired the skills that were stated in the learning objectives of the course. However, the learning objectives could be formulated in more detail in future. The project process was mostly graded the same by all evaluators, but most student groups gave the report a higher grade than the other evaluators did. The research results of the project courses showed that collaboration between university teaching and representatives of work life can be carried out in a manner in which all participants are satisfied. The challenges can turn into a positive learning experience if the course is implemented well. A significant input had been put into planning and preparing the courses examined. All participants considered the work life-based courses as educational, necessary and rewarding. The research data collected from the participants brought out useful information for developing course practices. Research-based development of teaching will also be important in the future.

\section{ACKNOWLEDGEMENTS}

We are grateful for the students, clients and supervisors for participating in the courses and in the study. Research was partly supported by the Academy of Finland [Grant 285 806]. Participation in the EDULEARN18 conference was funded by the "Opetuksen toteutuksen Digiloikka" [Implementing Digileap in Teaching] project by the University of Helsinki.

\section{REFERENCES}

[1] University of Helsinki, "Helsingin yliopiston tutkintoja ja opintoja koskevat linjaukset. HY/495/00.00.06.00/2017. Appendix 19.6.2017."

[2] University of Helsinki, "Tieteestä toimintaa -projektikurssit", 2015. Retrieved from https://www.helsinki.fi/fi/tieteesta-toimintaa-projektikurssit

[3] S. E. M. Everwijn, G. B. J. Bomers, and J. A. Knubbem, "Ability- or competence-based education: bridging the gap between knowledge acquisition and ability to apply," Higher Education, vol. 25, pp. 425-438, 1993. 
[4] J. S. Lee, S. Blackwell, J. Drake, and K. A. Moran, "Taking a leap of faith: redefining teaching and learning in higher education through project-based learning", Interdisciplinary Journal of Problem-Based Learning, vol. 8, no. 2, 2014, https://doi.org/10.7771/1541-5015.1426

[5] University of Helsinki, "Projektityö", 2017. Retrieved from https://courses.helsinki.fi/fi/maat-005

[6] A. Morgan, "Theoretical aspects of project-based learning in higher education", British Journal of Educational Technology, vol. 14, no. 1, pp. 66-78, 1983.

[7] S. Bell, "Project-based learning for the 21st century: skills for the future," The Clearing House: $A$ Journal of Educational Strategies, Issues and Ideas, vol. 83, no. 2, pp. 39-43, 2010.

[8] D. W. Johnson, and R. T. Johnson, "Making cooperative learning work," Theory into Practice, vol. 38, no. 2, pp. 67-73, 1999.

[9] M. Tsay, and M. Brady, "A case study of cooperative learning and communication pedagogy: does working in teams make a difference?," Journal of the Scholarship of Teaching and Learning, vol. 10, no. 2, pp. 78-89, 2010.

[10] K. Hakkarainen, J. Lallimo, and S. Toikka, "Kollektiivinen asiantuntijuus ja jaetut tietokäytännöt. Aikuiskasvatus, vol. 32, no. 4, pp. 246-256, 2012.

[11] A. Sfard, "On two metaphors for learning and the dangers of choosing just one," Educational Researcher, vol. 27, no. 2, pp. 4-13, 1998.

[12] H. Aarnio, "Oppimisen ohjaaminen" in Ammattipedagogiikkaa uuteen oppimiskulttuuriin (Eds. S. Helakorpi, H. Aarnio \& M. Majuri), pp. 155-178, Hämeenlinna: HAMK Ammatillinen opettajakorkeakoulu, 2010.

[13] S. Paavola, and K. Hakkarainen, "The knowledge creation metaphor - An emergent epistemological approach to learning," Science \& Education, vol. 14, no. 6, pp. 535-557, 2005.

[14] M. Lakkala, A. Toom, L. Ilomäki, and H. Muukkonen, "Re-designing university courses to support collaborative knowledge creation practices," Australasian Journal of Educational Technology, vol. 31, no. 5, pp. 521-536, 2015.

[15] H. Muukkonen, M. Lakkala, A. Toom, and L. Ilomäki, "Assessment of competences in knowledge work and object-bound collaboration during higher education courses" in Higher education transitions: Theory and research (Eds. E. Kyndt, V. Donch, K. Trigwell, and S. Lindblom-Ylänne, pp. 288-305, USA: EARLI book series New Perspectives on Learning and Instruction, Routledge - Taylor \& Francis Group, 2017.

[16] S. Paavola, M. Lakkala, H. Muukkonen, K. Kosonen, and K. Karlgren, "The roles and uses of design principles for developing the trialogical approach on learning," Research in Learning Technology, vol. 19, no. 3, pp. 233-246, 2011.

[17] V. Braun, and V. Clarke, "Using thematic analysis in psychology," Qualitative Research in Psychology, vol. 3, pp. 77-101, 2006.

[18] P. Mäkelä, H.-R. Kymäläinen, M. Lakkala, and H. Muukkonen, "Aiempien maataloustieteiden opintojen merkitys projektityön toteuttamisessa," Yliopistopedagogiikka, vol. 24, no. 2, pp. 43-46, 2017.

[19] H. Muukkonen, K. Kosonen, P. Marttiin, P. Vesikivi, J. Kaistinen, and G. Nyman, "Pedagogical design for knowledge creation in customer projects," Knowledge Management \& E-Learning, vol. 5, no. 3, pp. 278-297, 2013.

[20] University of Helsinki, "Projektinhallinta- ja työelämätaidot", 2017. Retrieved from https://courses.helsinki.fi/fi/maat-004

[21] H.-R. Kymäläinen, M. Lakkala, K. Kamppari, and E. Carver, E., Opas projektityöskentelyyn. Helsinki, Tieteestä toimintaa -verkosto, University of Helsinki, 2016. 